1994

\title{
Lawyers and Family Life: New Directions for the 1990's
}

Mary Jane Mossman

Osgoode Hall Law School of York University, mjmossman@osgoode.yorku.ca

Source Publication:

Feminist Legal Studies. Volume 2 (1994), p. 61

Follow this and additional works at: https://digitalcommons.osgoode.yorku.ca/scholarly_works

Part of the Legal Profession Commons

(c) $($ i) $९ \bigodot$

This work is licensed under a Creative Commons Attribution-Noncommercial-No Derivative Works 4.0 License.

\section{Recommended Citation}

Mossman, Mary Jane. "Lawyers and Family Life: New Directions for the 1990's." Feminist Legal Studies 2 (1994): 61

This Article is brought to you for free and open access by the Faculty Scholarship at Osgoode Digital Commons. It has been accepted for inclusion in Articles \& Book Chapters by an authorized administrator of Osgoode Digital Commons. 
Feminist Legal Studies Vol.II no.2

[1994] LAWYERS AND FAMILY LIFE:

NEW DIRECTIONS FOR THE 1990's

by

MARY JANE MOSSMAN** Part

Two: The Search for Solutions

Responding to the influx of women attorneys, the legal profession has changed in recent years, making room for mothers and, indirectly, fathers. But so far the changes are like a crack in a granite foundation, and the women who form the blade of the chisel may find themselves as pinched as the metaphor suggests. ${ }^{1}$

This dramatic description of the role of women lawyers in gaining entry to the legal profession neatly captures their creativity and energy in forging a place for themselves within the legal workforce, and the incredible challenge they continue to face in doing so. The sociological description is more pointed: "as women have entered the work force, both women and the work force have changed. What still have to change are the workplace and men. "2

The survey reports on women lawyers in Canada and the United States show great variety in the arrangements which women have adopted to maintain both meaningful legal work and family lives. The statistics demonstrate that, more often than men, they work in settings which allow greater flexibility in time commitments, including part time positions or other arrangements with reduced 
hours. Especially in the United States, there are numerous publications and consultants which offer guidance to individuals and to law firms about different kinds of alternative work arrangements. ${ }^{3}$ Some women lawyers in Canada have worked on alternative work schedules; however, none of these arrangements is widespread in either Canada or the United States and most of them are much less available in private practice law firms than in other legal workplaces. In rethinking the issue of work and family for the legal profession, however, it is important to understand the range of available options and the ways in which they may be utilized to achieve the goals of an integrated workforce of men and women.

\section{i. Alternative WorkSchedules}

There are a number of differing kinds of alternative work schedules which can be utilized to enable workers to accommodate workplace and family demands. In the context of the legal profession, there are four main kinds of arrangements which will be considered here: re-structured full time work; reduced work time options; leaves; and technological innovations. In assessing the merits of each, it is critical to recognize both the variety of arrangements available and the need to tailor arrangements to suit the particular circumstances of workplaces and of lawyers. Moreover, just as the fact that such arrangements have been utilized rarely in the past does not make 
them "unworkable", so there is a need to accept responsibility for flexibility and accommodation, on the part of both workplaces and lawyers, in assessing the results of initial experiments with these alternative arrangements.

a. Restructured full time work:flexitime and compressed work weeks

"Flexitime" means that all employees must work core hours established by the employer, but that employees may work the total hours required according to their own schedules. "Compressed work weeks" mean that the hours per week worked are compressed into fewer days. While such arrangements may be useful for workplaces with "normal" hours each week, it has been suggested that neither of these alternatives is very useful in large private law firms because the total number of hours usually worked makes it impossible to have time left over for flexitime or to compress such long hours into fewer days; "it is hard to compress a seventy-hour workweek into fewer than five days and still do anything else. "4

Despite this pessimistic conclusion, it is important not to assume that this arrangement is unworkable for any lawyers just because it seems less useful for the majority of those who work in large private law firms. Moreover, even within this job setting, and probably in a number of others, such an arrangement might work quite well. For example, a divorced parent (male or female) in a large law firm who 
has custodial responsibilities for children on weekends, but not during the week, might be able to accommodate a compressed work week quite successfully without disadvantaging the firm or its clients, particularly where the lawyer's work lends itself to such a schedule. The point is that such an arrangement may be workable for some women lawyers and their firms, even though it is not likely to be suitable for those women lawyers (perhaps a majority) who have family responsibilities on a daily basis.

b. Reduced work timeoptions: part time,job sharing and phasing out

These alternative work arrangements involve working fewer hours per week than the norm. The definition of "part time work" in large law firms is notoriously elusive, however, and frequently still involves working more than 40 hours per week.5 Within the part time arrangement are a number of different options, including work ing part of every day, working fewer than the normal number of days per week, working a total number of hours per year but with less regular hours, billing a defined number of hours per year with flexible time, etc. According to the ABA manual, however, there are two key aspects of policies for alternative work schedules which are especially relevant to part time work: 
Two primary components of an alternative schedule are the specification of the hours, days or percentage of expected billable and nonbillable hours that the alternative schedule attorney is to work, and an acknowledgement that flexibility on the part of the firm and the attorney is necessary to achieve these goals ... ${ }^{6}$

Linda Marks has suggested that "part-time in law firms seems to work best when figured in terms of billable hours or billable plus nonbillable hours worked per year, rather than a certain number of hours per week. "7 However, she suggests that there are a range of options, some of which may suit some areas of practice while other options seem to work better in others. At this point, our limited experience with real efforts to design part time work for lawyers means that it is too early to determine that one arrangement is preferable, or the only one which works. Moreover, in discussing part time arrangements, it is essential to define clearly what we mean by "part time work" since it may connote very different hours and responsibilities in different contexts. It is important to consider the part time issue not only by itself, but also in the context of accompanying arrangements which make it feasible and attractive to law firms.

"Job sharing", for example, may be combined with part time schedules as a response to arguments about the costs involved in part time arrangements, costs relating to office space and support staff , for example, who may still be required on a full time basis. While job sharing can mean that two lawyers share cases and clients, it can also 
simply mean that two lawyers "share an office or secretary, and provide backup to one another on cases. "8 Such an arrangement requires both lawyers and the firm to be flexible; as the ABA report noted:

It is the responsibility of reduced schedule attorneys to make sure that matters for which they are responsible are being handled properly, even if that means coming in to work on a 'non-working' day or making phone calls from home. Lawyers should be explicitly told about the need for flexibility. ${ }^{9}$

Assuming that the firm and the lawyers can achieve a workable and flexible arrangement, the idea of job sharing in this way may be both practicable and even helpful in creating a sense of teamwork within the legal workplace.

By contrast with part time work and job sharing arrangements, "phasing out" is generally well-established as an option for reduced work in large law firms. It has been used traditionally for senior members of firms who want to phase out of practice gradually. As has been suggested, widespread acceptance of this practice in law firms significantly "weakens the argument that part-time is 'impossible' in law firms"; ${ }^{10}$ at the same time, its practical utility for women lawyers has been negligible because of the small numbers of women who have reached senior levels of the profession. Nonetheless, the existence of these arrangements offers a compelling precedent for the feasibility of part time arrangements 
more generally, especially in large law firms; what is needed is imagination and commitment to design responses to these new challenges.

c Leaves: maternity, parental, and adoption; dependent-care, family illness; educational, political ; and sabbatical

Included in the options for alternative work arrangements are leaves from practice, some of which may be provided with pay or partial pay. According to the ABA report, leaves for purposes of "maternity, paternity or adoption" should be distinguished from

leaves for other purposes because the goals for the former leaves are specific to childbirth and adoption; the ABA report has identified the goals of leaves for maternity, paternity and adoption as follows:

i to afford lawyers a reasonable amount of time for recuperation from childbirth;

ii. to allow lawyers the time necessary to adjust to the demands of childrearing;

iii. to ensure that lawyers will return to work in good health and with high morale; and

iv. to demonstrate the importance the firm places on the family lives of its lawyers 11 
The ABA report also recommended a three-stage process of maternity leave, with a period of 6 weeks paid leave for maternity, 10 additional weeks of paid leave for childcare purposes, and a further period of 8 weeks of unpaid leave for childcare; in addition, the ABA recommended a reduced work schedule on return to work to enable the lawyer to become an effective working parent. As the report stated, "a return to a full billable hour workload from a zero billable hour workload would be jarring under any circumstances."12 By contrast with maternity leave, the existence of extended periods of leave for childcare, other "dependent-care" or "family illness" appears to be quite rare in the legal profession, particularly in large law firms. Indeed, the Transitions report suggested that the absence of such arrangements was an important reason for the disproportionately low number of positions in such firms held by women lawyers, by contrast with their male colleagues. According to the Transitions survey, women lawyers currently accommodate work and family demands by exiting from (especially law firm) workplaces, and re-entering (if at all) a few years later in different workplaces. ${ }^{13}$ Such patterns obviously present significant costs to individual lawyers but it is also costly for firms; as one consultant to law firms suggested:

Would you let a $\$ 100,000$. piece of equipment walk out the door? That's what the ABA estimates it costs to replace an associate. There are many cases where attorneys are leaving firms after three or four years, just 
when they are becoming of value to the firm, and going to firms that have more reasonable personnel policies. ${ }^{14}$

Because leave arrangements for family purposes have been relatively rare, it is difficult to assess how effective they might be in stemming the tide of "exits" by women lawyers, and it is also hard to suggest principles which should guide firms which might wish to adopt them. At the same time, it is crucial to recognize that our lack of experience with them means that we certainly do not know that they are "unworkable"; by contrast, we do know that there is a significant pattern of "erosion" of women lawyers from firms at considerable cost to individual lawyers, to law firms, and to the profession as a whole, a situation which demands the profession's serious attention.

Moreover, we do know that leaves for other purposes have of ten been successful arrangements. Lawyers have traditionally taken both "educational" and "political" leaves, and have re-entered firms after a number of years' absence. In some cases as well, lawyers have taken "sabbatical leaves" and returned to the same workplace. While the purposes of these leaves are different from those required to meet familial responsibilities, it is less clear that it follows that leaves for familial purposes should never be available. An energetic woman lawyer who is making a contribution at a firm may be no less able to work effectively after her two-year old is in school, or after she has nursed an elderly parent with a terminal illness. By contrast, a law firm mentality which assumes that all its lawyers 
are fungible and that there is no need to take account of family circumstances, by contrast with educational or political ambitions, stands to lose valuable personnel. Obviously it also sends messages (to men as well as to women) about the firm's values in terms of family life, values which are unrealistic and inappropriate in the context of an integrated workforce of men and women lawyers.

\section{d. Telecommuting or flexiplace}

This alternative work arrangement is one for which there is only quite recent experience in the legal profession, although it has frequently been suggested as useful for ensuring communication and flexibility for lawyers involved in part time work arrangements in the United States. 15 As Marks has explained, moreover, it is an option which may become more attractive with further experience, both because of the flexibility it offers for lawyers and the potential savings in costs, especially overheads for law firms:

With flexiplace, people work off-site part of the time, usually from home or from a satellite office near their home, and in effect commute by computer. [During the San Francisco earthquake in October 1989,] the major link between the East Bay and San Francisco was down and people could not get to work. Suddenly, law firms that had said, 'We couldn't possibly have people working from home' ... were asking 'How do we get people to work from home?' ... Firms were willing to try flexiplace 
because it would be to their advantage ...16

While the option of working at home full time with the assistance of technology may not be attractive by itself , technology significantly increases lawyers ' flexibility to work in different locations and at different times. In conjunction with other options (including part time), it therefore offers ways for women lawyers to work more effectively in the context of family responsibilities.

\section{ii. Alternative Work Schedules and The Needfor Structural Change}

Thus, there are a number of alternative strategies for accommodating work and family life within the legal profession, strategies which are available to both men and women. At the same time, it is clear that such opportunities have been available to women lawyers only infrequently, and that they have been even less available to those in private practice, especially in large firms. It is important to consider alternative work strategies not in the abstract, but in the context of the three powerful and "hidden" issues identified in this paper; indeed, in my view, effective and lasting solutions depend absolutely on our willingness to confront "hidden" questions about the nature of legal work, gendered experiences of social life, and ideas about "family" responsibilities.

Only if we re-think the nature of legal work, separating its fundamental nature from the traditions which underly current practices 
; only if we appreciate the ways in which gender affects our perceptions and expectations of men and women, including those who are lawyers ; and only if we recognize the ways in which changing patterns of family life and workplace par ticipation require new responses -can we begin to design policies which meet the needs of current and future generations of lawyers for both meaningful work and family life. Such an approach is also the only way to ensure that the consequences of choosing alternative work strategies do not automatically result, especially for women lawyers, in systematic exclusion from the most prestigious positions in the legal profession : the problem of "the glass ceiling".17

In searching for solutions, Joan Williams also concluded that women will never have equal opportunity with men in the legal profession so long as the pattern of legal work is defined by the model of the male worker without significant familial responsibilities. On this basis, she argued that real solutions require structural change, and she considered three possible changes in the structure and organization of work. One would require that men change their behaviour "and give up their unquestioned claims to the domestic labour of women. "18 For Williams, such a solution seemed unworkable on a broad scale since only some men would be likely to adopt this approach, thereby creating two streams of men who are lawyers: those on the "daddy track", disproportionately clustered along with 
women in the lowest positions in the profession, by contrast with those without family responsibilities at the highest levels of the profession.

A second solution, therefore, is to identif y the problem as lack of adequate childcare and relieve both men and women who are lawyers from providing it. For Williams, however, this second solution also involved serious disadvantages. In the first place, "it does not abolish, but only changes" the existing system; fathers still shift family responsibilities to women, although the female caregivers are no longer their wives, but "less privileged women" ${ }^{19}$ who provide childcare and household help for wages. In terms of a societal solution (as opposed to an individual one), such an arrangement is fundamentally inappropriate since it would achieve an integrated legal workforce of men and women at the expense of those women who provide such caregiving, women who are often the most marginalized workers and the most disadvantaged in terms of race and class in Canadian society. In addition to this factor, moreover, Williams has pointed out that this solution depends on a widespread change in our twentieth-century "norms of parents ' involvement with childrearing":

We must decide that we are untroubled when parents see their children only a very limited number of hours a week. We must further decide that we are untroubled when both parents have a relationship with their children that many women would describe as inadequate, and equiva 
lent to missing out on their children's childhoods. In short, we must redefine the ideal parent along the lines of traditional fatherhood. ${ }^{20}$

Thus, while recognizing that some women lawyers have "chosen" the solution of alternative caregivers, to greater or lesser degrees, Williams concluded that it was not workable as a broadly-based solution either within the legal profession or in society as a whole.

By contrast with these solutions, Williams advocates "a direct challenge to the gendered structure of wage labour", one that would confront the inordinate time demands which create "inconsistency between the roles of ideal worker and responsible parent." Such an approach requires a reassessment of the fundamental nature of work and a challenge to traditional ideas about arrangements for working ; it also requires a new definition of "ideal workers" as persons with family responsibilities. For Williams, moreover, the legal profession of fers an excellent place to create a challenge to male gender privilege in the workforce, particularly because of the profession 's current search for more meaningful work arrangements:

The legal context seems particularly promising as an educational tool because the time demands are often so excessive that even male lawyers see them as disfiguring the broader goals they have set for their lives. This may make it easier to see women's childrearing aspirations as part of a larger pattern of aspiration in which work demands are balanced with other goals. The legal profession also illustrates the dynamic by which mothers are barred from elite positions of power and responsibility. 
This inaccessibility dramatizes how the structure of wage labour constantly recreates male gender privilege. ${ }^{21}$

Like Williams, others have linked the solution to the work and family dilemma with the legal profession 's current search for renewal and personal satisfaction. In David Chambers' study of male and female graduates of the University of Michigan Law School, for example, he reported that those members of the profession who experienced the highest level of stress were also those who expressed the greatest level of satisfaction with their lives overa11; 22 interestingly, this group of lawyers was composed of women with children, and their satisfaction levels were higher than women lawyers without children and than men lawyers with or without children. According to Chambers, the research data showed that lawyers were generally more satisfied when they achieved balance in their lives:

The paradox this article has explored has been that, despite the double burden that women with children bear, the Michigan women we studied are well satisfied with their careers and generally satisfied with the balance of work and family. Some people, it appears, enjoy the triat/ialon. Some people like scaling mountains carrying babies on their backs ... ${ }^{23}$

Undoubtedly, this description is accurate for some women in the profession, although it may be important to determine whether the women who excel in achieving balance and satisfaction as described in Chambers ' study are also among those women lawyers who are 
eventually thwarted by the glass ceiling. Moreover, by contrast with Chambers, a more recent American survey found that women lawyers were disproportionately dissatisfied with their work as lawyers by comparison with men; the survey results suggested that women experienced relatively more negative features in their work environments and relatively fewer positive features (including the opportunity to advance) compared to men. ${ }^{24}$ And Williams has also suggested that there is recent evidence that "the crushing strain of inconsistent demands is grinding down women 's sense that they can control their lives and meet their responsibilities to others." 25

Overall, the recent survey reports in both Ontario and British Columbia tend to confirm these latter views, identifying women lawyers ' frustrations (and some men 's) with the "choices" available to them. Thus one male lawyer stated:

I wish there were more time to pursue non-professional activities and to spend with my children and wife. There is too much to do in our one life, and the law takes up too great a proportion of it, leaving me less

rounded and involved than I would choose to be. ${ }^{26}$

For both male and female lawyers who are frustrated by their inability to combine work and family life, exit from the profession remains an individualized "solution", one which may offer more personal satisfaction in terms of work and family but one which also fails to challenge the profession or its "hidden" assumptions. By contrast, those who remain in the profession, and especially in large 
law firms, are more likely to be those who conform most closely to the traditional concept of "ideal worker", a person without significant family responsibilities: men much more of ten than women. On this basis, the profession 's current search for renewal is occurring at the same time as many women (and some men) in the profession are abandoning it; thus, at least some of those who have most to offer in terms of the need for balance between work and family, those who have been systematically discouraged about their roles as workers with families, and those who might be most amenable to experimental and interesting changes in working arrangements are not involved in the profession's reexamination of its goals and practices.

\section{Conclusion: Responding to Lelia Robinson's Question}

Attracting and retaining the best legal talent in the 1990's will require accommodating management policies to the new demographics of the legal profession: female and male lawyers in roughly equal numbers, many of them balancing the demands of dual careers and new families, others struggling with single parenthood or ailing parents, still others needing windows of flexibility to accomplish a variety of important life goals. These lawyers are committed to the profession, but have competing demands in their lives which must be balanced. ${ }^{27}$

The search for solutions for the work and family dilemma begins with a definition of the problem. This paper has argued that the 
problem should be defined in terms of the structure of the legal profession as a whole, both now and in the future; and that the issue of accommodating the balance between work and family is fundamental to the longterm interests of an integrated workforce of men and women. For these reasons, the work and family dilemma needs to be understood as integrally connected to previous patterns of exclusion in the legal profession (for women and for others); and to issues of professional responsibility for achieving substantive equality goals within the legal profession as well as in the Canadian legal system. In addition, this paper has suggested that the adoption of alternative work arrangements is unlikely to accomplish the goals of an integrated workforce so long as the exercise of such options continues to be linked to the glass ceiling, for women and also for men.

Thus, this paper argues that solutions to the work and family dilemma will be more useful if they begin by recognizing that the profession is in the midst of fundamental changes in demography; and that it is no longer possible to argue that women lawyers must either conform to the status quo or exit from the profession. Instead, the future of the profession depends on its willingness to change to accommodate the needs of workers with family responsibilities, the vast majority of whom are now women; and to do so in ways that also permit men who are lawyers to better balance their work and family lives now and for the future. 
Changing Expectations: Lawyers and Firms

At the present time, the creation of different working patterns to accommodate family life is most of ten a matter of individual negotiation and decision-making. In such a context, consultants have often approached these issues with women lawyers on an individualized basis. Thus, women lawyers who are mothers have been advised to make careful preparations for their requests for alternative work arrangements, and to start such preparations several years in advance. According to Sheila Nielsen, for example, women lawyers should start by selecting a good workplace:

The best way to work part-time is to pick a workplace that is open to alternative options. Become a knowledgeable consumer. Talk to alumni who work there or used to work there. Find out how requests for parttime work have been treated ... Find out how management feels about alternative options. Does the firm have a policy? Read it, but don 't assume the workplace supports part-time options simply because it has a policy. 28

Nielsen also advises women lawyers to work full time for several years before seeking a reduced hours option, to pick a specialty carefully (so as to be "marketable" and also to be able to maintain client service with alternative work arrangements), and to develop 
both a track record for excellence and professionalism as well as "true mentors". ${ }^{29}$ Despite the soundness of this advice as a personal strategy for individual women lawyers, however, even Nielsen concedes that it may not all be within their control:

Sometimes ... it may be difficult to know whether your mentor is a true supporter. One attorney I counselled who worked at a corporation believed her mentor was arguing her case to management, but learned through the grapevine that he was actually lukewarm about a reduced hours arrangement. He never told her about his doubts, and acted as if he were pleased about the prospect of having her work reduced hours ... ${ }^{30}$

In such a context, it seems necessary for women lawyers to ensure, in addition to Nielsen' s suggestions, an excellent connection to the firm grapevine! More importantly, it suggests the need for more systematic action as well as the individual efforts of women lawyers. Recognizing the need for broader policy and planning in law firms, Nielsen has also advised lawyers to seek to have appropriate policies adopted in the firm before making individual requests. ${ }^{31}$ In her view, the most effective way to develop such policies is through a committee of concerned lawyers at all levels in the firm or workplace, male as well as female. ${ }^{32}$ The ABA report similarly recommended the adoption of express policies within legal workplaces and the creation of a broadly-based workplace committee to bring forward draf t proposals; according to the ABA 
report:

The membership [of such a committee] should be diverse, composed of partners and associates of various ages and both sexes. Ideally, parents and non-parents should be on the committee, as should people with specific perspectives, such as adoptive or single parents. If there are lawyers at the firm with expertise in the relevant employment and discrimination law, one or more of them should be included. Most important, the committee should be comprised of respected members of the firm who appreciate the importance of the issues to be addressed, who can assist in commu nicating these issues to other partners, associates, and staff , and who will add credibility to the process. ${ }^{33}$

The ABA report recommended also that the committee should become familiar with applicable law relating to firm policies and consult with people both inside and outside the firm with expertise in implementing them. It also made suggestions for communicating the adoption of a new policy within the firm , cautioning that "the manner in which a policy is presented is crucial to setting the tone for its reception and support. '134 Moreover, the ABA report stressed that ongoing monitoring of the implementation of such policies is just as important as the process of initial drafting, and recommended that a timeframe for reevaluation be established from the outset.

Inthe context of these practical suggestions, it is important to note that the fundamental message of the ABA report is that firms and other workplaces need to approach these issues on the basis that 
current changes within the profession require us to seek solutions to the work and family dilemma in the interests of everyone. Moreover, the ABA report suggests that it is not only the professional norms of equality which demand such action, but also because such policies represent sound business practice in the sense that firms must remain competitive to retain the best legal talent, and to provide efficient client service:

These policies are also the keystones of a businesslike approach to the delivery of legal services. Insisting on historical work patterns may deter highly skilled and experienced lawyers from staying with a firm and its clients, and client service and satisfaction will suffer. Nothing frustrates clients more than having their matters constantly shifted to new lawyers. Not only must a new relationship be established, but the client of ten must foot the bill while the file is once again reviewed. Flexible work policies make it possible to keep the talent a firm has nurtured and maintain a high level of continuity in client relationships. ${ }^{35}$

Consistent with this approach to the work and family dilemma, the ABA report 's recommendations directly confront the problem of the glass ceiling in relation to alternative work schedules. Thus, for example, the report recommends that a period of parental leave should not interrupt employee benefits and, perhaps more significantly, should not affect progression toward partnership for associate lawyers. ${ }^{36}$ Similarly, the recommendations for alternative work schedules eliminate the fact of such schedules from 
consideration in relation to partnership:

Clearly, the experience, expertise and other effects of tenure gained while working on an alternative schedule do not fall into a black hole. Professional growth has the same value whether acquired on a fullor part-time basis. Accordingly, time spent on an alternative work schedule should be counted as part of the progression toward partnership. ${ }^{37}$

The report also commented on women lawyers ' "choices" to elect voluntarily not to seek partnership status. According to the ABA report , such an election "should not preclude an attorney from opting to return to partnership track as an alternative work schedule or fulltime attomey." 38 Finally, the report addressed ten "myths about why alternative work schedules do not work," 39 including the possibility that one failed effort at alternative work scheduling in a law firm should not lead to a conclusion that it can never work:

Some firms were dissatisfied with their first and only alternative schedule attorney, and now take the attitude that this experience proves such arrangements do not work. Remember that a sample of one is not statistically valid. People leave law firms for many different reasons. Alternative schedules fail for many reasons -most of which are not predictors of whether the next arrangement will work. Some attorneys leave even if the arrangement is working ... There should be honest communication between the alternative schedule attorney who either departs or returns to full-time status before anticipated, so that the firm can learn from the experience and the policy can be adjusted , if necessary 
TheProcess ofChange

Overall, therefore, the ABA report approaches the search for solutions to the work and family dilemma from the perspective of a need for structural changes in the profession and in the culture of legal work. Its tone is extremely positive, reflecting a sense that the profession can accomplish these changes effectively through rational discussion and decision-making. From the perspective of her involvement in such discussions about change in the legal profession, moreover, Lynn Hecht Schafran has also emphasized the importance of lawyers ' exploration of these ideas. According to her, investigating gender bias in the legal profession in the United States has been a "transformative experience" for many participants:

... the investigation process is a transformative experience. The judges, lawyers, and others who serve on these task forces range from individuals with extensive backgrounds in the area of gender bias ... to members who openly are sceptical, if not hostile, to the idea that such a problem exists. But af ter months of listening [to testimony of experiences]; after reviewing the answers to surveys and hypotheticals; af ter reading transcripts, decisions and studies; most members conclude that, in the words of a highly respected lawyer and member of the New York Task Force who was totally new to the issue of gender bias ...' 
there is a very serious problem out there, and no one knows about it. ' ${ }^{41}$

On this basis, the creation of opportunities for lawyers to exchange views about their experiences in the profession, both in the context of the CBA Task Force 's work and within individual firms and other settings, might be expected to lead to the kinds of changes recom mended in the ABA report.

At the same time, it is important to take account of the subtle ways in which current dynamics in the profession may prevent open and meaningful discussions from taking place, and to challenge all those involved (especially those in senior positions in large firms) to take responsibility for overcoming these barriers. In the first place, there may be apparent reluctance among members of a firm, especially women, to consider alternative work arrangements. Such reluctance frequently results from knowledge of the consequences which have usually attached to such arrangements in the past (including the glass ceiling), and firms thus may need to make more than cursory inquiries to obtain realistic responses. As Marsha Simms suggested:

Women [like men] are also ambivalent about other women working parttime. On one hand, most women want to have children or are supportive of women who do, and realize that working full-time in a large firm and being a full-time mother is difficult, if not impossible. On the other hand, many women worry that different trea tment of 
women is inconsistent with equal treatment, and that part-time work reinforces the view that women are not committed to their careers. ${ }^{42}$

Moreover, women 's responses to such inquiries may differ significantly at different points in a legal career ; as Simms pointed out, young women lawyers focus on "the nature of the work they are getting, and whether they are receiving the same opportunities as their male contemporaries." Women who have been lawyers somewhat longer are more interested in issues of evaluation and promotion, "and are also dealing in a very real way with the issues of childbirth and returning to work after having children"; while more senior women are primarily concerned about issues of "management responsibilities, client relationships, and allocations of power and prof its. "43 Thus, even discussions among women lawyers may result in differing views about the need for solutions to the dilemma of work and family, a factor which needs to be seriously taken into account by task forces as well as workplaces in the process of making structural changes within the profession. What is critical is that differing points of view as to problems and solutions must not become a reason for failing to confront the work and family dilemma.

Related to this issue is another factor which may influence the outcome of discussions about structural changes in the profession in 
relation to work and family: the profession 's traditional stance toward criticism and dissent. A process of change which relies on mutual education through discussion must also relinquish a definition of "loyalty" (to the profession or to an individual workplace) which requires the absence of criticism or challenge to the status quo. Anecdotal evidence suggests that women lawyers currently must choose either to remain "loyal" through an absence of such criticism ${ }^{44}$ or suffer the consequences of such challenges to the status quo in reduced workplace opportunities (of ten leading to exit from the profession). Justice Elizabeth Evatt has cautioned women lawyers against accepting the narrowness of such alternatives, while recognizing the seriousness of the problem:

While it is hard to change the system from outside, operating inside it causes a dilemma for women who are called on to act in accordance with the established rules and hierarchies of that system ... The twin dangers of either absorbing the culture and ignoring its bias, or of totally rejecting its insensitivity have to be overcome if a genuine attempt is to be made to bring about a fundamental change in the institution and its values. ${ }^{45}$

All of us who engage in discussions about structural change in the legal profession must seriously examine the extent to which the consequences of criticism and dissent may muffle or silence the voices of those whose experiences need to be understood to address the work and family dilemma successfully. 46 In this context, finally, it is important to understand this process of change within the 
profession as ongoing and incremental, one which continues to exact costs for women lawyers disproportionate to those of their male colleagues because of gender, and which operates to exclude some women more than others because of race, class and marital or other status. While it may no longer be necessary for most women practitioners to remain unmarried or childless, it is still easier to "succeed" in a traditional legal career by doing so for women, while such considerations do not so systematically constrain men. Some women have made these "choices" to make a career their priority nonetheless, while other women have "chosen" to put their careers second to family; and the fact that some women (usually white, middle-class and married) have succeeded in having both families and "successful" careers should not blind us to the fact that there are many more men than women lawyers who have done so. In each case, moreover, women tend to experience costs of their "choices", whatever they are, disproportionately to men in the profession.

And while a few women have challenged more directly the need to make any such "choice", all too little is known of the costs they have experienced; what has happened to those women lawyers who made the first claims for part time work arrangements in their workplaces and whose requests were routinely denied? Where are these "lost" women lawyers, and how can we use their expertise and experience in designing policies in the context of larger numbers of 
women lawyers making these requests now and in the future? Eleanor Fox has suggested two kinds of models for women lawyers: marginalists and activists. As she has described them,

Some inroads are made by individuals not naturally accorded a place in the hierarchy but who feel at home in the environment, believe that there is a meritocracy, and excel at what they do. By being such good performers and so accepting of their environment, they weaken stereotypes and catalyze change at the margins in a positive unthreatening way. Other inroads are made by activists, who see inequities as pervasive and the decision-makers as self-consciously strategizing to preserve their own positions of privilege.

While activists may see marginalists as tokens, activists are of ten seen as trouble makers and not team-players. The very fact of their activism may tend to moderate their rise up the ladder of 'meritocracy ', on which con geniality and diplomacy are 'merits'. Thus, activists pave or push the way for others to rise in the establishment. For lasting change toward equality of opportunity, we need both -persistent activists and persevering traditionalists. ${ }^{47}$

This characterization of differing strategies for change on the part of women lawyers captures some of the ways in which women lawyers have responded to the challenges presented by their unequal status within the profession and their pressing needs to solve individual problems including the work and family dilemma. At the same time, this assessment may not reflect the complexity of women's responses, and the fact that some women may define themselves as marginalists 
on some issues and activists on others; indeed, the two categories might better be seen as the ends of a spectrum, with women lawyers ranged fully along it and with some women changing their roles during the course of a legal career. There is anecdotal evidence that some women who achieve traditional "success" in the profession, for example, become activists only at that point in their careers, while others choose activism at an earlier stage and forego traditional "success". For those who are interested in change in the legal profession, there is a very important issue about recognition among us of these differing contributions and the differential costs they may entail. Especially for those of us who benefit from the pioneering actions of women who made claims which have allowed us to make our present "choices", there is a need not to take for granted the costs which have been paid, and to continue to work for changes which ensure that women and men can work effectively as lawyers in an integrated profession for the future. ${ }^{48}$

Only by doing so can we truly answer Lelia Robinson's onehundred-year-old question: 


\section{End Notes}

* Excellent research assistance by Michael Gardner and Elizabeth Nastasi at Osgoode Hall Law School is gratefully acknowledged. Research for this paper was originally undertaken for the Canadian Bar Association's Task Force on Gender Equality in the Legal Profession.

** Professor of Law, Osgoode Hall Law School of York University. 1. Martha Freeman, "Writing Briefs and Changing Diapers", California Lawyer 6(1986), 36.

2. Linda Marks, "Alternative Work Schedules in Law: It's About Time", New York Law Scltool Law Review 35 (1990), 361, at 362; and quoting A. Hochschild (with A. Machung), Second Shift: Working Parents and tile Revolution at Home (New York: Viking, 1989), 12-13(emphasis in original). According to Hochschild, most workplaces have remained inflexible in the face of family demands on the part of their workers, and at home, most men have yet to really adapt to the changes in women's workforce participation; the author refers to this situation as "the stalled revolution", one that affects not only women, but also men and the whole family structure.

3. See, for example, Commission on Women in the Profession, "Lawyers and Balanced Lives: A Guide to Drafting and Implementing Workplace Policies for Lawyers" (Chicago: American Bar Association, 1990), a publication which provides advice and sample policies for law firms with respect to parental leave, alternative work schedules, and sex ual harassment. See also Marks, supra n.2; Sheila Nielsen, "The Balancing Act: Practical Suggestions for Part-Time Attorneys", New York Law School Law Review 35 (1990), 369; and Marsha Simms, "Women in the Lawyering Workplace: A Practical Perspective", New York Law School Law Review 35 (1990)' 385.

4. Marks, supra n.2, at 363.

5. According to Marks, supra n.2, one lawyer who usually worked 70 hours per week reduced his hours by $80 \%$ but maintained his billings at $90 \%$; thus, he worked about 63 hours per week, an arrangement which she suggested did "not seem very part-time."

6. ABA report, supra n.3, at II-4. The ABA report also makes clear that such arrangements must always be distinguished from the "reduced work schedule" which should be available to women lawyers returning to the firm after maternity leave; that is, maternity leave and the accompanying need for reduced work schedules for a short period on return to work should be addressed quite separately from these part time arrangements.

7. Marks, supra n.2, at 364 .

8. Marks, s11pran.2, at 365.

9. ABA report, supra n.3, at II-9.

10. Marks, supra n.2, at 365 .

11. ABA report, supra n.3, at 1-5. These goals are stated in gender 
neutral language, although it seems clear that i. would apply only to birth mothers and not to birth fathers or adoptive parents; and that iii. might be more applicable to birth mothers than to the others, although not exclusively so. Defining goals in gender neutral language thus obscures dif ferences in the circumstances being addressed by the policy. In this example, it might be preferable to define goals for each kind of leave sepa rately; thus, the goals for maternity leave would be defined differently from those for paternity or adoption leaves; in each case, goal iv. would undoubtedly appear. It may also be arguable that iv. should be placed first in this list of goals for parental leave policies.

12. ABA report, supra n.3, at I-5. It is important to Note that these recommendations occurred in the context of the United States which does not have a national maternity leave policy; as Marks stated (at 365), in relation to maternity leave policies, the United States is "on the level with South Africa and Upper Volta." In the Canadian context, therefore, where the concept of paid maternity leave is an established part of legal and institutional arrangements, the ABA recommendations appear quite consistent and workable for the legal profession. In 1993, the Family and Medical Leave Act was enacted in the United States, requiring employers with 50 or more workers to provide up to 12 weeks of unpaid leave for family medical emergencies, childbirth or adoption (see New York Times, 15 August 1993, at E-3).

13. See Transitions (Toronto: Law Society of Upper Canada, 1991), 58. The data shows very strong relationships between women 's role in childcare and their exits and re-entry to the legal workplace. Asked to identify their primary activities between first and second positions and between second and third, $21 \%$ of women stated childcare as their primary activity between first and second positions and 35\% did so regarding their activity between second and third professional positions. No men indicated childcare as a primary activity in either situation, a response that is as dramatic as it is perplexing. (The other choices were travel, further education, unem ployed, illness or injury and "other "; by far the highest percentages of men indicated either unemployed or travel as their primary activities both between their first and second positions, and between their second and third.)

14. Marks, supra n.2, at 366 .

15. ABA report, sitpra n.3, at II-9: Some alternative schedule attorneys find that they can successfully field questions and problems by speaking to their clients or offices from home. If feasible, they can install a separate telephone line to handle a message machine, a fax and/or a computer to isolate business-related calls.

16. Marks, supra n.2, at 366. See also Andree Brooks, "Making Offices Compatible With Flexible Sched ules" (New York Times, October 4, 1992) for suggestions about cost savings involved in re-designing workplaces so that each employee has a dedicated telephone line and laptop computer, along with filing cabinets on wheels, but no "dedicated" office. According to some industry specialists, such arrangements permit companies to "divert more 
resources to improving the field support for these workers, like providing more laptop computers, cellular phones and fax machines"; others have suggested that the concept has become more at tractive as more corporations utilize flexible work hours, part time arrangements and job sharing. In a critique of this paper, Dorothy Quann made some usef ul suggestions about alternative arrangements and the need for law firms to re-think what an "office" needs to be for law practice in the 1990's and beyond.

17. I have argued elsewhere that the legal doctrine of separate spheres which was used to exclude women from entering the legal profession at the turn of the century now may be an apt description of the differing roles of men and women lawyers within the profession -with male lawyers disproportionately at the top of the profession and women disproportionately represented at the lower end. See Mossman, "' Invisible '

18. Constraints on Lawyering and Leadership: The Case of Women Lawyers", Ottawa Law Review 20 (1988), 567. See also J. Hagan, M. Huxter and P. Parker, "Class Structure and Legal Practice: Inequality and Mobility among Toronto Lawyers", Law and Society Review 22 (1988), 9.

19. Nate18 Joan C. Williams, "Sameness Feminism and the Work/Family Conflict",

20. New York Law Sc/100/Law Review 35(1990), 347, at 355-356.

21. Williams, supra n.18, at 355-356.

22. Williams, supra n.18, at 356. See also Karen Czapanskiy, "Volunteers and Draftees: The Struggle for Parental Equality", UCLA Law Review 38(1991), 1415. According to Czapanskiy, fathers are given support in the legal system for being "volunteer parents, people whose duties toward their children are limited ", while mothers are "draftees, people whose duties toward their children are extensive"; thus, she proposed a "reconceptualization of parenthood ". For an excellent analysis of the precarious position of "domestic workers" in Canada, see Aud rey Macklin "Foreign Domestic Worker: Surrogate Housewife or Mail Order Servant?", McGill

23. LawJournal37(1992), 682.

24. Williams, supra n.18, at 356. A thoughtful analysis of the need for societal change in arrangements for "caring" is found in Don Edgar, "Sharing the Caring: Rethinking Current Policies", Family Matters 31(1992), 40.

25. David Chambers, "Accommodation and Satisfaction: Women and Men Lawyers and the Balance of Work and Family", Law and Social Inquiry 14 (1989) , 251. The study focused specifically on the ways in which men and women lawyers accommodated their multiple roles as parents and lawyers. 26. Chambers, supra n.22, at 287 (emphasis added). Chambers' research did not directly address links between women lawyers' choices to accommodate work and family on one hand, and the ways in which such choices subsequently affected career progress: the glass ceiling problem. A similar view about the satisfaction of balancing work and family was expressed by Epstein in 1981 when she characterized the competing 
demands of work and family for women lawyers as energizing:

a. I found in my investigations of the lives of women lawyers that when faced with numerous demands, many did not feel a sense of strain or negative stress. Rather, these women found their lives ex- citing and dramatic. They developed greater energy when the demands proliferated, rather than feeling drained, and often did not define their situation as problematic.

27. Cynthia Fuchs Epstein, Women in Law (New York: Basic Books, 1981),

$28 . \quad 315-326$.

29. Ronald L. Hirsch, "Will Women Leave the Law?", Barrister 16 (1989),

22.

30. Williams, supra n.18, at 355 .

31. Note 26 Transitions, supra n.13, at 78.

32. ABA report, supra n.3, at 5. The ABA report clearly identified the ba lance of work and family as only one of a number of reasons for re-thinking the need for ever-increasing numbers of billable hours. As the report stated: a. Beyond the need to accommodate family demands, the best women and men in the legal profession are more often attracted to work places that recognize and respect their broader responsibilities and outside interests, such as pro bono and community activities, involvement in political organizations, and CLE and law school teaching. The extraordinary increase in expected billable hours over the last fifteen years ... is making it extremely difficult for lawyers to pursue these other interests. Lawyers in firms are aware that there are other types of challenging work that do not require billing 2000- 2500 hours per year. They are leaving law firms and the law to find it, resulting in a brain drain that the profession should be seeking to stem.

33. Sheila Nielsen, supra n.3, at 375-376. Nielsen also Note $d$ that it is always more difficult to be the first person to challenge the status quo of workplace arrangements (at 376):

a. $\quad$ Try to find a workplace where reduced hours options are already in b. $\quad$ place and working well. Many of the frontier-women who blazed the trail for future attorneys are legends now because they were unable to work out a good long-term part-time arrangement, and have long since left the firm or workplace. Remember, the first reduced hours arrangements are of ten learning experiences for everyone.

34. Nielsen, supra n.3, at 376-377.

35. Nielsen, supra n.3, at 376 .

36. As Nielsen, supra n.3, has argued (at 379): "Cutting an ad hoc deal at the time of pregnancy is playing with fire. Success or failure may depend upon whether the managing partner thinks women should be home with the children, whether he or she likes you, whether your specialty is valu - able enough to the workplace, whether your mentor is powerful enough, and a myriad of other factors outside your control that can bring your ca - reer to a grinding halt. Policies [by contrast] allow people to plan their futures." 
37. According to Nielsen, s11pra n.3, it is often useful to include "elder statesmen" members of the firm who "are learning about the value of red uced hours options from their daughters, as their daughters try to balance career and family." She also cautions against letting preconceived notions about co-workers prevent their participation, citing her own reluctance to involve her extremely hard-working supervisor in such discussions at her work place ; "surprisingly, this supervisor turned out to be very interested in parttime work. My supervisor was Scott Turow and he was working on his book, Presumed Innocent and is now a part-time partner at a large Chicago firm." Nielsen, supran.3, at379.

38. ABA report, supran.3, atl-7.

39. ABA report, supra $\mathrm{n} .3$, at l-8.

40. ABA report, s1tpra n.3, at I-6. According to the report, "without policies that are responsive to the needs of its lawyers, a firm's costs will rise as turnover escalates."

41. ABA report, s1tpra n.3, at 1-7. Note that the ABA distinguished between the periods of paid parental leave (six weeks plus ten weeks) from any additional period of unpaid leave (up to two months).

42. ABA report, supra n.3, at II-14. Acceptance of this basic principle does not mean that there can be no flexibility; as the report further stated: "A firm may decide that working less than full time will result in a pro rata, slower progression toward partnership. If so, this should be articulated in the firm 's policy. But meeting the criteria for partnership depends on the capabilities of the individual. It is therefore possible for an alternative schedule attorney to progress at a faster rate than a pro-rata formula may suggest."

43. ABA report, supra n.3, at II-15. The report stressed, moreover, that: "It is key that such an alternative be voluntary, uninfluenced by firm policy or pressures, and that a firm 's policy offer this option only in addition to alternative work schedule partnership track opportunities. Otherwise the policy amounts to a controversial and unnecessary 'Mommy Track' ."

44. These "myths" are (at II-22 to II-26):

a. Doomed tofail-aself-fulfilling prophecy

b. Profitability, productivity and the "floodgate fear"

c. Part-time lawyers are unproductive and unprofitable

d. This only works in large firms

e. Itcan't work for litigators; it can 't work for transactional attorneys

f. I can't train someone who is not here full time

g. I'd like to sit at home in my garden, too

h. I can never find the alternative schedule attorney

i. Clients don't accept part-time lawyers

j. We tried it once and it didn't work

45. ABA report, supran.3, atII-26.

46. Lynn Hecht Schafran, "Gender and Justice: Florida and the Nation", Florida Law Review 42 (1990), 181, at 202. Schafran has also suggested that "even the women on these task forces who begin with some knowledge about gender bias in the courts and the legal profession emerge with new 
insight into the pervasive, deeply rooted nature of the problem."

47. Simms, supra n.3, at 388 .

48. Note 43 lbid.

49. The "grapevine" in Toronto, for example, suggests that quite disproportionate numbers of women lawyers (by contrast with men in the same cohorts) have recently been asked to depart from large firms, but there have been no formal complaints, to my knowledge; significantly, perhaps, some of these same firms have made substantial contributions to the CBA Task Force on Gender Equality, a position which suggests their openness to reviewing current practices. In the academic context, on the other hand, there has been more vocal criticism and challenge on the part of women faculty and, to some extent students, perhaps because of women 's relatively more secure positions in these workplaces; see, for example, Sheilah Mcintyre, "Gender Bias Within the Law School: 'The Memo' and its Impact", Canadian Journal of Women and the Law 2 (1987-8), 362, especially at 389-390; and Bruce Feldthusen, "The Gender Wars: 'Where the Boys Are"', Canadian Journal of Women and the Law 4(1990), 66.

50. Justice Elizabeth Evatt , AO, "Foreward ", in R. Graycar and J. Morgan, T11e Hidden Gender of Law (Leichhardt, N.S.W. (Australia): The Federation Press, 1990), vi.

51. This issue was addressed more fully in Mossman, "Gender Bias and the Legal Profession: Challenges and Choices", in J. Brockman and D. Chunn, eds., Investigating Gender Bias in Law: Socio-Legal Perspectives (Toronto: Thompson Educational Publishing Inc., 1993).

52. See Eleanor Fox, "Being a Woma n, Being a Lawyer and Being a Human Being -Woman and Change", Ford ham Law Review 57 (1989), 955, at 962- 963.

53. Such a commitment to action is best expressed by my favourite Judaic saying: "You are not required to complete the task; neither are you free to desist from it." 